\title{
Author Correction: Large-scale targeted sequencing identifies risk genes for neurodevelopmental disorders
}

Tianyun Wang (1D, Kendra Hoekzema, Davide Vecchio (D, Huidan Wu, Arvis Sulovari D, Bradley P. Coe, Madelyn A. Gillentine (D), Amy B. Wilfert, Luis A. Perez-Jurado, Malin Kvarnung, Yoeri Sleyp, Rachel K. Earl, Jill A. Rosenfeld (10, Madeleine R. Geisheker (D), Lin Han, Bing Du, Chris Barnett, Elizabeth Thompson, Marie Shaw, Renee Carroll, Kathryn Friend, Rachael Catford, Elizabeth E. Palmer, Xiaobing Zou, Jianjun Ou, Honghui Li, Hui Guo (D), Jennifer Gerdts, Emanuela Avola, Giuseppe Calabrese, Maurizio Elia, Donatella Greco, Anna Lindstrand (D), Ann Nordgren (D), Britt-Marie Anderlid, Geert Vandeweyer, Anke Van Dijck (D), Nathalie Van $\operatorname{der}$ Aa, Brooke McKenna, Miroslava Hancarova, Sarka Bendova, Marketa Havlovicova, Giovanni Malerba, Bernardo Dalla Bernardina, Pierandrea Muglia, Arie van Haeringen, Mariette J. V. Hoffer (D), Barbara Franke (D), Gerarda Cappuccio, Martin Delatycki, Paul J. Lockhart (1), Melanie A. Manning, Pengfei Liu (D), Ingrid E. Scheffer, Nicola Brunetti-Pierri (1), Nanda Rommelse, David G. Amaral, Gijs W. E. Santen, Elisabetta Trabetti, Zdeněk Sedláček, Jacob J. Michaelson (D), Karen Pierce, Eric Courchesne (D), R. Frank Kooy (D) \& The SPARK Consortium, Magnus Nordenskjöld, Corrado Romano (1), Hilde Peeters, Raphael A. Bernier, Jozef Gecz (D), Kun Xia (1) \& Evan E. Eichler (iD

Correction to: Nature Communications https://doi.org/10.1038/s41467-020-18723-y, published online 1 October 2020.

The original version of this Article contained an error on page 5 of the Results section, which incorrectly read 'They are characterized by craniofacial dysmorphisms (9/10), thin vermillion border and lips (4/7), and feeding difficulties (6/11), and exhibit neonatal hypotonia (10/7)'. The correct version states 'They are characterized by craniofacial dysmorphisms (9/10), thin vermillion border and lips (4/7), and feeding difficulties (6/11), and exhibit neonatal hypotonia (7/10)'.

Published online: 21 October 2020

\footnotetext{
(c) (1) Open Access This article is licensed under a Creative Commons Attribution 4.0 International License, which permits use, sharing, adaptation, distribution and reproduction in any medium or format, as long as you give appropriate credit to the original author(s) and the source, provide a link to the Creative Commons license, and indicate if changes were made. The images or other third party material in this article are included in the article's Creative Commons license, unless indicated otherwise in a credit line to the material. If material is not included in the article's Creative Commons license and your intended use is not permitted by statutory regulation or exceeds the permitted use, you will need to obtain permission directly from the copyright holder. To view a copy of this license, visit http://creativecommons.org/licenses/by/4.0/.
}

(c) The Author(s) 2020 